\title{
Hydrolysis of maize starch using amylolytic enzymes extracted from sorghum malt
}

\author{
Ayoade Lateef ADEJUMO ${ }^{1}$, Femi Kayode AGBOOLA ${ }^{2 *}$ and \\ Stephen Kolawole LAYOKUN ${ }^{1}$ \\ ${ }^{1}$ Department of Chemical Engineering, Obafemi Awolowo University, Ile-Ife 220005, Nigeria. \\ ${ }^{2}$ Department of Biochemistry, Obafemi Awolowo University, Ile-Ife 220005, Nigeria. \\ "Corresponding author, Email: fkagbo@oauife.edu.ng, Tel: +2348034738078
}

\begin{abstract}
Amylases, $\alpha$-amylase (EC 3.2.1.1, $\alpha$-1, 4-glucan-4-glucanohydrolase) and glucoamylase (EC 3.2.1.3, $\alpha-1,4 ; \alpha-1,6$-glucan glucohydrolase; amyloglucosidase), extracted and partially purified from sorghum malt were used to hydrolyze maize starch. The process and products of the enzymatic hydrolysis were also compared with that of acid hydrolysis using hydrochloric acid. Maize grains were dry milled into flour as starch used for the hydrolytic procedures. Green (for glucoamylase) and dry (for $\alpha$-amylase) sorghum malts were homogenized and the amylases were extracted in appropriate buffer solutions, precipitated by ammonium sulphate and desalted by column chromatography. Acid hydrolysis was investigated under various temperature, acid concentrations and starch concentrations. The combination of acid-enzyme hydrolyses involved the use of $0.1 \mathrm{M} \mathrm{HCl}$ followed by the addition of the extracted $\alpha$-amylase and glucoamylase and enzyme-enzyme $(\alpha-$ amylase and glucoamylase) hydrolyses were also investigated. The results of the acid hydrolysis showed that the concentration of reducing sugar produced increased with temperature of hydrolysis and the concentrations of the acid. However, the products decreased with increasing starch granule concentration. The overall study showed that enzyme-enzyme hydrolysis has the highest dextrose equivalent of $47.0 \%$ followed by acidenzyme with $43.0 \%$ and the acid hydrolysis with $27.0 \%$.
\end{abstract}

(C) 2009 International Formulae Group. All rights reserved.

Keywords: $\alpha$-amylase, glucoamylase, maize (Zea may), Sorghum bicolor (Sorghum).

\section{INTRODUCTION}

Starch is a plentiful carbohydrate resource beside cellulose, consisting of two moieties- amylose and amylopectin. Starch is produced commercially from seeds, tubers and roots of plant. Starch is not only an important ingredient of human diet, but also has uses in other fields dating back to the beginnings of civilization. Starch can, by virtue of its various chemical and physical properties, be processed into products that can have a variety of performance applications. Starch can be chemically, physically or enzymatically modified by polymer degradation, oxidation, crosslinking and substitution. These vary from use as an energy carrier to use as an adhesive to a variety of food or feed applications or use as a source of the chemical glucose used as a feed stock for the fermentation industry, and also in paper and textile industries (Whistler et al., 1984). Starch has become acknowledged as a raw material for the production of an energy carrier, as it can be fermented to ethanol, which can be as a gasoline extender or ethanol fuel itself (Van Beynum and Roels, 1985; Venkatasubramanian and Keim, 1985). For all sources of ethanol production, maize is probably the most attractive because of its abundant supply, low price and high by- 
product value which is not reduced by selective extraction of the starch conversion (Venkatasubramanian and Keim, 1985). Moreover, maize has the highest metabolizable energy (ME) (Job, 1993). Maize has several advantages over cassava and other starchy crops. Its crop cycle is relatively shorter and is very easy to cultivate in very large quantity (Fakorede, 2001).

Acid hydrolysis of starch has had widespread use in the past. The discovery of starch hydrolysis by acid to glucose leading to the development of pyrodextrins, laid the foundation for large starch-based industries producing dextrose and dextrin. Various works done on acid hydrolysis of starch favour the use of dilute hydrochloric acid because it acts mildly on starch with lesser amount of side products (Swason and Cori, 1948; Thompson et al., 1953). Sulphuric and phosphoric acids produce a lot of side products which ultimately inhibit the process of hydrolysis and growth of microbes (Peppler and Perlman, 1980). However, acid is now largely replaced by enzymatic processes, as it required the use of corrosion resistant materials, gave rise to high colour and salt-ash content (after neutralization), needed more energy for heating and was relatively difficult to control. Payen and Persoz (1835) were the first to demonstrate the enzymatic starch hydrolysis by malt amylase extract which converted starch to sugar before a fungal amylase was employed for commercial syrup manufacture in 1938 (Dale and Langlois, 1940). This first fungal amylase preparation contained a mixture of glucoamylase and $\alpha$ amylase and was used for further hydrolysis of an acid hydrolyzate (Schenck, 1992). Commercial success was achieved by replacing acid hydrolysis by enzymatic starch hydrolysis which majorly contributed to raising the total world market of starch hydrolysate products, to some 2 million metric tons in 1995/1996 (HRA, 1997). The two enzymes used in combination in the industry for starch hydrolysis to glucose are $\alpha$-amylase (EC 3.2.1.1, $\alpha$-1,4-glucan-4-glucanohydrolase) which catalyses the endo-cleavage of $\alpha-1,4-$ glycosidic linkages and releases short oligosaccharides and $\alpha$-limit dextrins; and glucoamylase (EC 3.2.1.3, $\alpha$-1,4; $\alpha$-1,6-glucan glucohydrolase; amyloglucosidase) which catalyses the complete exo-cleavage of starch (amylase and amylopectin) and maltooligosaccharide to glucose.

Sorghum grain is capable of developing enough $\alpha$-amylase, $\beta$-amylase, and glucoamylase enzymes during malting for hydrolytic process. A lot has been done on the hydrolysis of maize starch using enzymes in mashed-grain sorghum malt (Ilori, 1991; Ogundiwin and Ilori, 1991; Ilori et al., 1991). Hence, this study is undertaken to investigate the potential of hydrolytic action of isolated amylases in sorghum malt on maize starch. The production of amylolytic enzymes from cereals' malts will drastically reduce the foreign exchange spent on importation of these important industrial products.

\section{MATERIALS AND METHODS}

Reagents and biological materials

Potassium iodide, iodine, glucose, maltose hydrate, starch soluble, sodium potassium tartarate, ammonium sulphate (enzyme grade) and albumin (from bovine serum) were products of Sigma Chemical Company, St. Louis, MO, USA. Sodium hydroxide, sodium dihydrogen orthophosphate, ammonium molybdate, sodium arsenate, sulphuric acid, hydrochloric acid, glacial acetic acid, sodium acetate and blue dextran were products of BDH Chemical Limited, Poole, England. Biogel P10 was a product of BioRad, Richmond, USA. Yellow maize variety as well as sorghum (Sorghum bicolor) was bought from the local market.

\section{Preparations of maize starch and sorghum malts}

Yellow maize in large quantity was screened to remove unwanted materials. It was then dried to constant weight at $50{ }^{\circ} \mathrm{C}$ in forced air oven. Germs and husks were removed by dehusking machine, leaving behind the endosperm. The endosperm was dry-milled into flour and stored. One gram of maize starch flour was gelatinized in $100 \mathrm{ml}$ distilled water. Five milliters of iodine solution $\left(0.5 \% \mathrm{KI}\right.$ and $\left.0.15 \% \mathrm{I}_{2}\right)$ was added to $1.0 \mathrm{ml}$ aliquot of the starch solution and brought to a final volume of $15 \mathrm{ml}$ by distilled water. The absorbance was measured at 550 $\mathrm{nm}$ against a blank containing $5.0 \mathrm{ml}$ of iodine solution brought to $15 \mathrm{ml}$ with distilled water. 
Absorbance reading was converted to starch concentration from a calibration curve of the reaction of soluble starch $(0.1$ to $1.0 \mathrm{mg} / \mathrm{ml})$ with iodine (Apar and Ozbek, 2004).

Sorghum grains were malted as reported by Ilori (1991). The sorghum grains were cleaned and steeped in water for 24 hours with changes of the steep liquor at 6 hours intervals. The steeped grain was germinated in a well ventilated germination chamber (previously disinfected with $1.0 \%$ formalin solution) at $30{ }^{\circ} \mathrm{C}$ for 4 days. During germination, the kernels were turned and wet twice daily with water. The germinated grains were divided into two portions. One half was kilned in a hot air oven at $50{ }^{\circ} \mathrm{C}$ (dry malt). The other half (green malt) was de-rooted by hand and milled before further processing.

\section{Estimation of sugar and protein concentrations}

Sugar estimation using either glucose or maltose standard was by measuring the reducing ends using various dilutions of $0.025 \%$ glucose or maltose by the NelsonSomogyi method (Nelson, 1944). The protein concentration was determined by the Biuret (Gornall et al., 1949) method using bovine serum albumin as standard.

\section{Enzyme assays}

The enzyme assays involved measuring the reducing sugar resulting from the hydrolysis of starch substrate. $\alpha$-amylase was assayed in a reaction mixture consisting of $0.5 \mathrm{ml}$ of soluble starch $(0.5 \% \mathrm{w} / \mathrm{v})$ gelatinized in $0.5 \mathrm{M}$ acetate buffer $(\mathrm{pH} 5.5)$ and $0.1 \mathrm{ml}$ enzyme. After incubation for 30 min at $40{ }^{\circ} \mathrm{C}$, the reaction was stopped by immersion in boiling water for 5 min, cooled and $0.4 \mathrm{ml}$ of distilled water was added to each of blank and the sample. A parallel blank consisted of $0.1 \mathrm{ml}$ distilled water and $0.5 \mathrm{ml}$ soluble starch. Then reducing sugars were measured using Nelson-Somogyi method (Nelson, 1944) using maltose as standard. Activity was expressed as milligram of reducing end produced per millilitre of enzyme per minute.

Glucoamylase activity was assayed according to the procedure described for the $\alpha$-amylase reaction above. The reaction mixture contained $0.5 \mathrm{ml}$ of starch substrate
(1.0\%) gelatinized in $0.5 \mathrm{M}$ acetate buffer, $\mathrm{pH}$ 4.5 at $40{ }^{\circ} \mathrm{C}$ for $30 \mathrm{~min}$.

\section{Isolation of enzymes o-amylase}

Flour from milled dry sorghum malt was extracted in 3 volumes of $0.5 \mathrm{M}$ sodium acetate buffer, $\mathrm{pH} 5.5$ by occasional stirring for 6 hours at room temperature. It was first filtered through cheese cloth to remove suspended particles, followed by centrifugation at 9,000 $\mathrm{g}$ at room temperature to remove insoluble materials. The supernatant was brought to $70 \%\left(\mathrm{NH}_{4}\right)_{2} \mathrm{SO}_{4}$ saturation (and left overnight in the refrigerator). The precipitate was collected by centrifugation at $15,000 \mathrm{~g}$ for $25 \mathrm{~min}$. and redissolved in a minimal amount of $70 \%$ $\left(\mathrm{NH}_{4}\right)_{2} \mathrm{SO}_{4}$ solution in acetate buffer and saved in the refrigerator.

Desalting was done by eluting the enzyme in Bio-Gel P-10 column chromatography.

\section{Glucoamylase}

Milled green sorghum malt was extracted in 3 volumes of $0.5 \mathrm{M}$ acetate buffer, $\mathrm{pH}$ 4.5. The remaining procedure was carried out as described for $\alpha$-amylase above. The precipitate separated by centrifugation was stored in $0.5 \mathrm{M}$ sodium acetate buffer saturated with $70 \%\left(\mathrm{NH}_{4}\right)_{2} \mathrm{SO}_{4}$.

\section{Hydrolyses \\ Acid hydrolysis}

Twenty grams and thirty grams of maize flour were weighed and dispensed into $100 \mathrm{ml}$ of $0.1 \mathrm{M} \mathrm{HCl}$ in different $250 \mathrm{ml}$ conical flasks and placed in an incubator shaker set at $250 \mathrm{rpm}$. The hydrolysis was then carried out at 40, 50, 60 and $70{ }^{\circ} \mathrm{C}$. At each temperature, samples were withdrawn at interval of $1.0 \mathrm{~h}$ for $12 \mathrm{~h}$. Further hydrolysis in each sample collected was stopped by neutralizing the acid with equal volume of 0.1 M NaOH before centrifugation. The supernatant collected was analyzed, for reducing sugars by the Nelson-Somogyi method (Nelson, 1944). Also, five different samples of $30.0 \mathrm{~g}$ of maize flour dispensed into $100 \mathrm{ml}$ of $0.1 \mathrm{M}, 0.2 \mathrm{M}, 0.3 \mathrm{M}, 0.4 \mathrm{M}$ and $0.5 \mathrm{M} \mathrm{HCl}$ solution respectively and hydrolyzed in an incubator shaker set at 250 $\mathrm{rpm}$ and $70{ }^{\circ} \mathrm{C}$. Samples was taken, 
neutralized, centrifuged and analyzed for reducing sugar as described earlier.

\section{Enzyme-enzyme hydrolysis}

Twenty grams and thirty grams of maize flour were weighed and each gelatinized in $100 \mathrm{ml}$ of $1.64 \mathrm{ft}$ acetate buffer, $\mathrm{pH} 5.5$ in $250 \mathrm{ml}$ conical flasks. The slurry was allowed to cool to $62{ }^{\circ} \mathrm{C}$ (Solomon et al., 2006) before the addition of the partially isolated $\alpha$-amylase enzyme preparation (1.0 $\mathrm{ml} / \mathrm{kg}$ of starch, 44 units $/ \mathrm{ml}, 36 \mathrm{mg}$ protein $/ \mathrm{ml}$ ). The reaction mixture was placed in an incubator shaker maintained at $62{ }^{\circ} \mathrm{C}$ and $250 \mathrm{rpm}$ for 35 hours, during which period, samples were withdrawn at $5 \mathrm{~h}$ interval. The reaction of the withdrawn samples was stopped by placing the samples in boiling water for $5 \mathrm{~min}$ and then centrifuged. The samples were then analyzed for reducing sugar. The temperature was then reduced to $60^{\circ} \mathrm{C}$ and $\mathrm{pH}$ adjusted to 4.5 , prior to addition of glucoamylase $(1.0 \mathrm{ml} / \mathrm{kg}$ of starch, 216.7 units $/ \mathrm{ml}, 28.8 \mathrm{mg}$ protein $/ \mathrm{ml})$. The hydrolysis was carried out further for 15 hours while samples were withdrawn at 5 hours interval and treated as above for reducing sugar.

\section{Acid-enzyme hydrolysis}

Ten grams and fifteen grams of maize flour were weighed, gelatinized in $50 \mathrm{ml}$ distilled water and dispensed into $50 \mathrm{ml}$ of 0.1 $\mathrm{M} \mathrm{HCl}$ in two $250 \mathrm{ml}$ conical flasks and hydrolyzed for 2 hours in the incubator shaker at $250 \mathrm{rpm}$ at $70{ }^{\circ} \mathrm{C}$ during which period, samples were taken at $5 \mathrm{~h}$ interval for analysis. The remaining mixture in the conical flasks were cooled down and neutralized with equivalent amount of $0.1 \mathrm{M} \mathrm{NaOH}$ solution. $50.0 \mathrm{ml}$ of $0.5 \mathrm{M}$ acetate buffer, $\mathrm{pH} 5.5$ was added to each of the mixtures and put in the incubator shaker at $62{ }^{\circ} \mathrm{C}$ and $250 \mathrm{rpm}$. At constant temperature of $62{ }^{\circ} \mathrm{C}, \alpha$-amylase $(1.0$ $\mathrm{ml} / \mathrm{kg}$ of starch, 44 units $/ \mathrm{ml}, 36 \mathrm{mg}$ protein $/ \mathrm{ml}$ ) was added. The mixture was hydrolysed for 15 hours during which period samples were taken at 5 hours interval. The temperature was later lowered to $60{ }^{\circ} \mathrm{C}$ and the $\mathrm{pH}$ adjusted to 4.5 prior to addition of glucoamylase $(1.0 \mathrm{ml} / \mathrm{kg}$ of starch, 216.7 units $/ \mathrm{ml}$, and $28.8 \mathrm{mg}$ protein $/ \mathrm{ml}$ ). Hydrolysis was carried out for another 50 hours. The supernatant of the centrifuged samples taken at 5 hours interval was analysed for reducing sugar.
Calculation of dextrose equivalent (DE)

$$
\text { Starch hydrolysis products }
$$

(maltodextins) are normally characterized by their dextrose equivalent (DE) value. It is defined as

$$
\text { D.E. }=\frac{\text { Reducing sugar concentration }}{\text { Total initial substrate concentration }} \times 100
$$

(Alexander, 1992; Schenck, 1992)

\section{RESULTS AND DISCUSSION \\ Starch concentration in maize flour}

The starch concentration in maize flour used was $0.62 \mathrm{~g} /$ dry weight of maize flour. This falls within the range of maize starch concentration of different varieties of malted maize grain (61.9-74\%) as reported by Adeyemi (1993).

\section{Activity of the isolated amylases from sorghum malt}

The crude enzyme preparations from malted sorghum grains showed the presence of $\alpha$-amylase and glucoamylase in the dry and green malts respectively. The results are summarized in Table 1.

In all, the activities of the enzymes were relatively high. These observations with Sorghum bicolor were different from those reported by Daiber (1975) where it was proposed that pigmented (colored) grain sorghum tends to have low enzyme and extract potential because of their high contents of tannins and polyphenols. However, the observations were in agreement with Agu and Palmer (1997) where they suggested that yellow or red sorghum variety developed higher enzyme than the white sorghum. Crude glucoamylase has the least protein concentration and activity. The use of the dry (kilned) malt for the $\alpha$-amylase was predicated on the fact that $\beta$-amylases are heatlabile, losing considerable activity during kilned. Selective inactivation of either $\alpha$ - or $\beta$ amylases in the presence of one another involves decreasing the $\mathrm{pH}$ of the enzyme extract below $4.0(\alpha)$ or heat treatment at 70 ${ }^{\circ} \mathrm{C} \quad(\beta)$ at neutral $\mathrm{pH}$ respectively (Muralikrishna and Nirmala, 2005). This step has been employed in the purification of 
Table 1: Activity of crude and partially purified enzyme from dry and green sorghum malts.

\begin{tabular}{|c|c|c|c|c|c|c|}
\hline Enzyme & $\begin{array}{l}\text { Volume } \\
\text { (ml) }\end{array}$ & $\begin{array}{l}\text { Protein } \\
(\mathrm{mg} / \mathrm{ml})\end{array}$ & $\begin{array}{c}\text { Activity } \\
\text { (units/ml) }\end{array}$ & $\begin{array}{c}\text { Specific } \\
\text { activity } \\
\text { (units/mg } \\
\text { of protein) } \\
\end{array}$ & $\begin{array}{c}\text { Protein/g } \\
\text { of malt }\end{array}$ & $\begin{array}{l}\text { Units/g } \\
\text { of malt }\end{array}$ \\
\hline $\begin{array}{l}\text { Crude } \alpha \text { - amylase } \\
\text { from dry malt }\end{array}$ & 600 & 45.0 & 32.0 & 0.71 & 135 & 96.0 \\
\hline $\begin{array}{l}\text { Crude glucoamylase } \\
\text { from green malt }\end{array}$ & 882 & 30.0 & 13.9 & 0.46 & 90 & 41.7 \\
\hline $\begin{array}{l}\alpha \text { - amylase } 70 \% \\
\left(\mathrm{NH}_{4}\right)_{2} \mathrm{SO}_{4} \text { precipitate } \\
\text { followed by desalting }\end{array}$ & 52.5 & 36.0 & 44.0 & 1.22 & 9.45 & 11.55 \\
\hline $\begin{array}{l}\text { Glucoamylase } 70 \% \\
\left(\mathrm{NH}_{4}\right)_{2} \mathrm{SO}_{4} \text { precipitate } \\
\text { followed by desalting }\end{array}$ & 78.8 & 28.8 & 216.7 & 7.52 & 7.7 & 58.0 \\
\hline $\begin{array}{l}\text { Glucoamylase } 70 \% \\
\left(\mathrm{NH}_{4}\right)_{2} \mathrm{SO}_{4} \text { precipitate } \\
\text { followed by desalting }\end{array}$ & 78.8 & 28.8 & 216.7 & 7.52 & 7.7 & 58.0 \\
\hline
\end{tabular}

$\alpha$-amylases to separate the heat labile $\beta$ amylases.

\section{Progress of acid hydrolysis:}

The progress of the hydrolytic action of $0.1 \mathrm{M} \mathrm{HCl}$ on $20 \%$ and $30 \%$ maize starch slurries with temperature are shown in Figures 1 and 2 respectively. Figure 3 shows the result of hydrolysis with different concentrations of $\mathrm{HCl}$. The curves in Figure 1 show that the sugar concentration reached peak after the $9^{\text {th }}$ hour at $60{ }^{\circ} \mathrm{C}$ and $70{ }^{\circ} \mathrm{C}$ hydrolysis with dextrose equivalent (DE) values of $18.0 \%$ and $18.75 \%$ respectively. Also, the curves in Figure 2 show that sugar concentration reached peak after the $7^{\text {th }}$ hour for $70{ }^{\circ} \mathrm{C}$ hydrolysis and after the $8^{\text {th }}$ hour for $60{ }^{\circ} \mathrm{C}$ hydrolysis with DE of $18.2 \%$ and $16.8 \%$ respectively. In both cases, it was observed that reducing sugar and rate of hydrolysis slightly increased with temperature. This can be explained on the basis that the increase in temperature increased the kinetic energy of both starch granules and acid molecules thereby increasing the rate of collision of the two particles and rate in which acid molecules randomly bombarded the glucosidic linkages, leading to more cleavage of these linkages and more production of reducing sugar. However, there was a slight decrease in reducing sugar concentration after the 10th hour of the hydrolysis process at $60{ }^{\circ} \mathrm{C}$ and $70{ }^{\circ} \mathrm{C}$ while no observable decrease after $10^{\text {th }}$ hour of hydrolysis process at $40{ }^{\circ} \mathrm{C}$ and $50{ }^{\circ} \mathrm{C}$. There might have been significant evaporation at 60 ${ }^{\circ} \mathrm{C}$ and $70{ }^{\circ} \mathrm{C}$ after 10 hours of hydrolysis to cause dehydration which could cause glucose decomposition. Miller and Cantor (1952) reported that D-glucose formed during starch hydrolysis process by acid, was dehydrated to 5-hydroxymethyl furfural as the main product and lesser amount of 2-hydroxymethyl furan. After 12 hours of hydrolysis process at $40{ }^{\circ} \mathrm{C}$ and $50{ }^{\circ} \mathrm{C}$, there was no sign of decrease in sugar concentration probably showing that there was no significant evaporation, at such low temperatures to cause noticeable dehydration. Rather, hydrolysis progressed up to the $12^{\text {th }}$ hour although at slower rate.

\section{Effects of different acid concentrations on maize starch slurry}

The result is shown in Figure 3 with apparent observation of increase in reducing sugar concentration and rate of hydrolysis with $\mathrm{HCl}$ concentration and time. The DE 


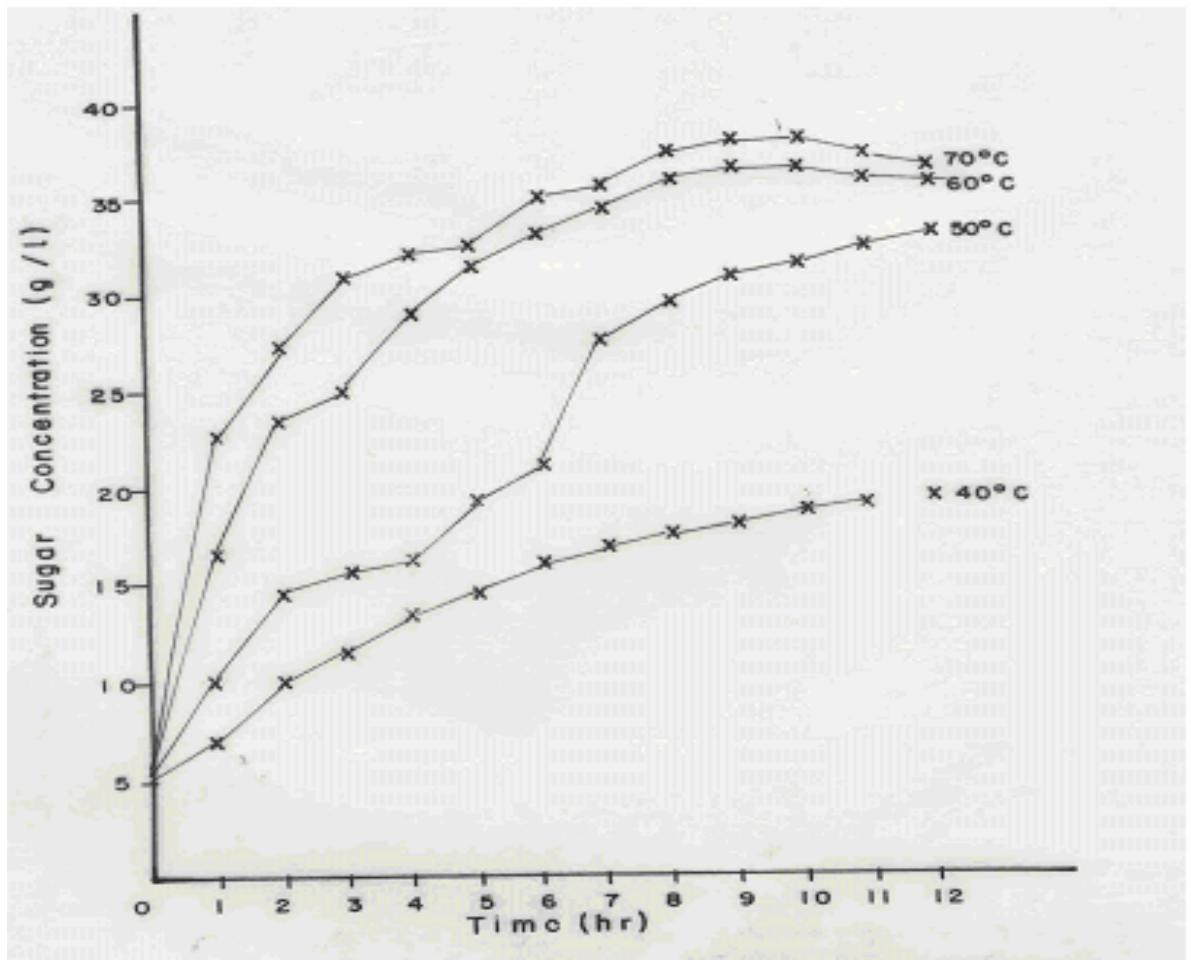

Figure 1: Variation of reducing sugar concentration (of $20 \%$ maize starch slurry) with time at different temperature and at $0.1 \mathrm{M} \mathrm{HCl}$ concentration.

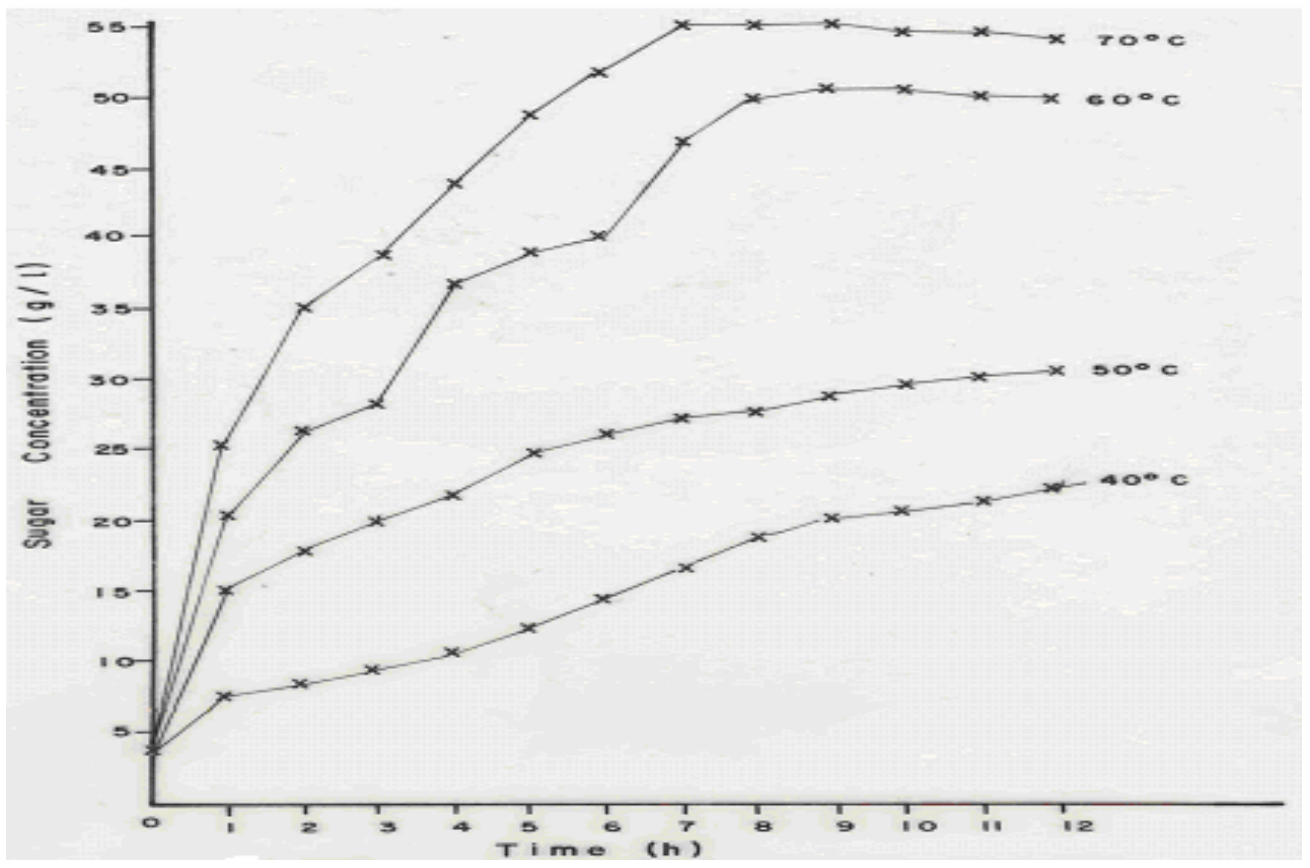

Figure 2: Variation of reducing sugar concentration (of $30 \%$ maize starch slurry) with time at different temperature and at $0.1 \mathrm{M} \mathrm{HCl}$ concentration. 
obtained at $0.5,0.4,0.3,0.2$ and $0.1 \mathrm{M}$ were $27.0, \quad 26.0, \quad 23.75, \quad 21.0$ and $19.0 \%$ respectively. This is in agreement with earlier work that the rate of hydrolysis was influenced by the catalyst concentration (Agra et al., 1969). This increase may perhaps, be due to the fact that with the increase in hydrochloric acid concentration, more hydrogen ions, $\mathrm{H}^{+}$, would be available to penetrate into greater proportion of the amorphous regions leading to the hydrolysis of amylose and amylopectin molecules. Wang et al. (2002) had found that both amylose and amylopectin were hydrolysed and the extent of hydrolysis was affected by the acid concentration.

\section{Effect of starch concentration on reducing sugar concentration}

Figure 4 shows the effect of starch concentration on the hydrolysis process. This is by comparing the hydrolytic action of $0.1 \mathrm{M}$ $\mathrm{HCl}$ on 20 and $30 \%$ maize starch slurries at 70 ${ }^{\circ} \mathrm{C}$. The 20 and $30 \%$ maize starch slurry have DE of 19.1 and $18.3 \%$ respectively. In these hydrolyses, the hydrogen ion concentration $\left(\mathrm{H}^{+}\right)$were the same but different quantities of starch granules. The DE of $18.3 \%$ of $30 \%$ maize starch slurry which is slightly less than $19.1 \%$ DE of $20 \%$ maize starch slurry, but of the same magnitude, indicates that the more the quantity of starch granules, the less the chance of penetration of hydrogen ions into amorphous regions, leading to less degradation of amylose and amylopectin molecules in starch and hence less reducing sugar produced.

\section{Enzymatic hydrolysis with time}

Figures 5 and 6 show the hydrolytic action of $\alpha$-amylase and glucoamylase on $20 \%$ and $30 \%$ maize starch slurry. After 25 hours of hydrolysis, there was no significant increase in reducing sugar concentration with time (Figures 5 and 6). This might perhaps be due to $\alpha$-amylase reaching its maximum activity level. When glucoamylase was introduced, there was a surge in sugar production as shown on the curve. At $65^{\text {th }}$ hour in Figure 5, the sugar production reached the peak and the concentration remained constant till the end of the experiment with $91.1 \mathrm{~g} / \mathrm{l}$ as the maximum reducing sugar produced. Also, Figure 6 shows reducing sugar reaching peak at $79^{\text {th }}$ hour with maximum $141.0 \mathrm{~g} / \mathrm{l}$ upon addition of glucoamylase. Reduction in activities of these enzymes was due to processing time as well as inhibitory effect of produced sugar. Apar and Ozbek (2004) suggested that temperature and processing time are involved in the inactivation of $\alpha$-amylases after the starch hydrolysis process.

Aderibigbe (2005) reported maximum reducing sugar concentration of $153 \mathrm{~g} / \mathrm{l}$ and $148 \mathrm{~g} / \mathrm{l}$ with $\mathrm{DE}$ of $51.0 \%$ and $49.3 \%$ for hydrolysis of $30 \%$ cassava flour slurry at 70 ${ }^{\circ} \mathrm{C}$ using commercial enzymes termamyglucoamylase and fungamyl-glucoamylase respectively, compared with $141 \mathrm{~g} / \mathrm{l}$, DE $47 \%$ obtained with $30 \%$ maize starch slurry of this study. Both values of $153 \mathrm{~g} / \mathrm{l}$ and $148 \mathrm{~g} / \mathrm{l}$ obtained by Aderibigbe (2005) are comparable with $141 \mathrm{~g} / \mathrm{l}$ obtained in this work. However, the difference in purity level of enzymes used could be attributed to the slightly higher reducing sugar concentration obtained with the commercial enzymes.

The results shown in Figures 5 and 6 have dextrose equivalent, $\mathrm{DE}$, of $45.0 \%$ and $47.0 \%$, respectively. During starch hydrolysis, DE indicates the extent to which the starch glucosidic linkages have been cleaved. In this study, it is observed that more bonds were broken in $30.0 \%$ maize starch slurry than in $20 \%$ maize starch slurry. This observation is contrary to the case of acid hydrolysis where by at constant hydrogen ion concentration, the numbers of glucosidic bonds cleaved are inversely proportional to the starch granules when other factors remain constant.

\section{Acid/enzyme hydrolysis}

This is a three-stage hydrolysis of $20 \%$ and $30 \%$ maize starch slurry with $0.1 \mathrm{M}$ $\mathrm{HCl}$ at $70{ }^{\circ} \mathrm{C}$, followed by $\alpha$-amylase and glucoamylase. Figures 7 and 8 summarized the results of acid-enzyme hydrolysis with three levels observed in each figure. The first level observed after the $15^{\text {th }}$ hour when hydrochloric acid reached peak of its catalysis with reducing sugar concentration of $34.0 \mathrm{~g} / \mathrm{l}$ and $46.0 \mathrm{~g} / \mathrm{l}$ respectively. The second level was observed after the $30^{\text {th }}$ hour with sugar concentration of $60.0 \mathrm{~g} / 1$ and $69.0 \mathrm{~g} / 1$ while the third level was observed after the $45^{\text {th }}$ hour with $76 \mathrm{~g} / \mathrm{l}$ sugar concentration in Figure 7 


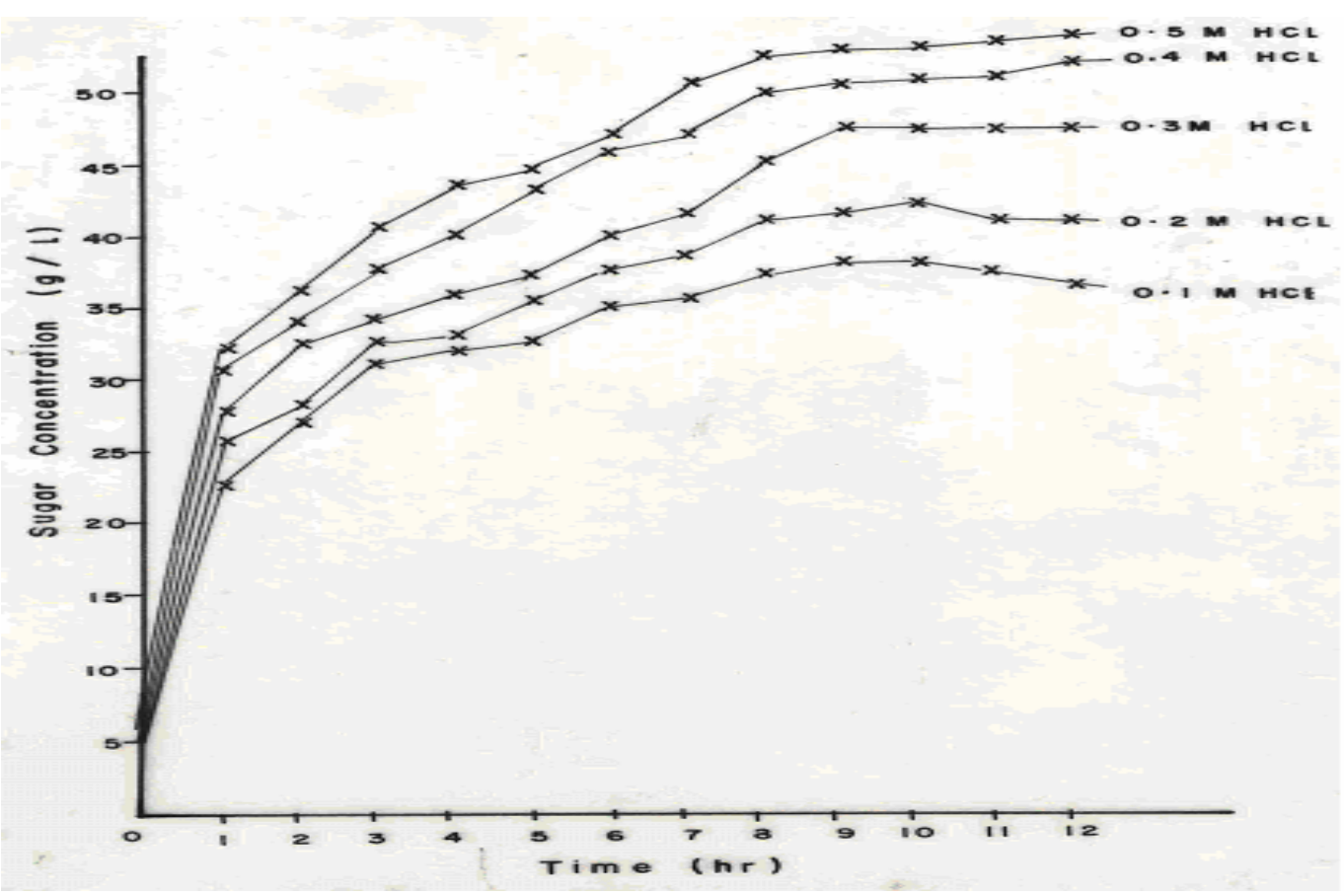

Figure 3: Variation of reducing sugar concentration with different acid concentration with time on $20 \%$ maize starch slurry.

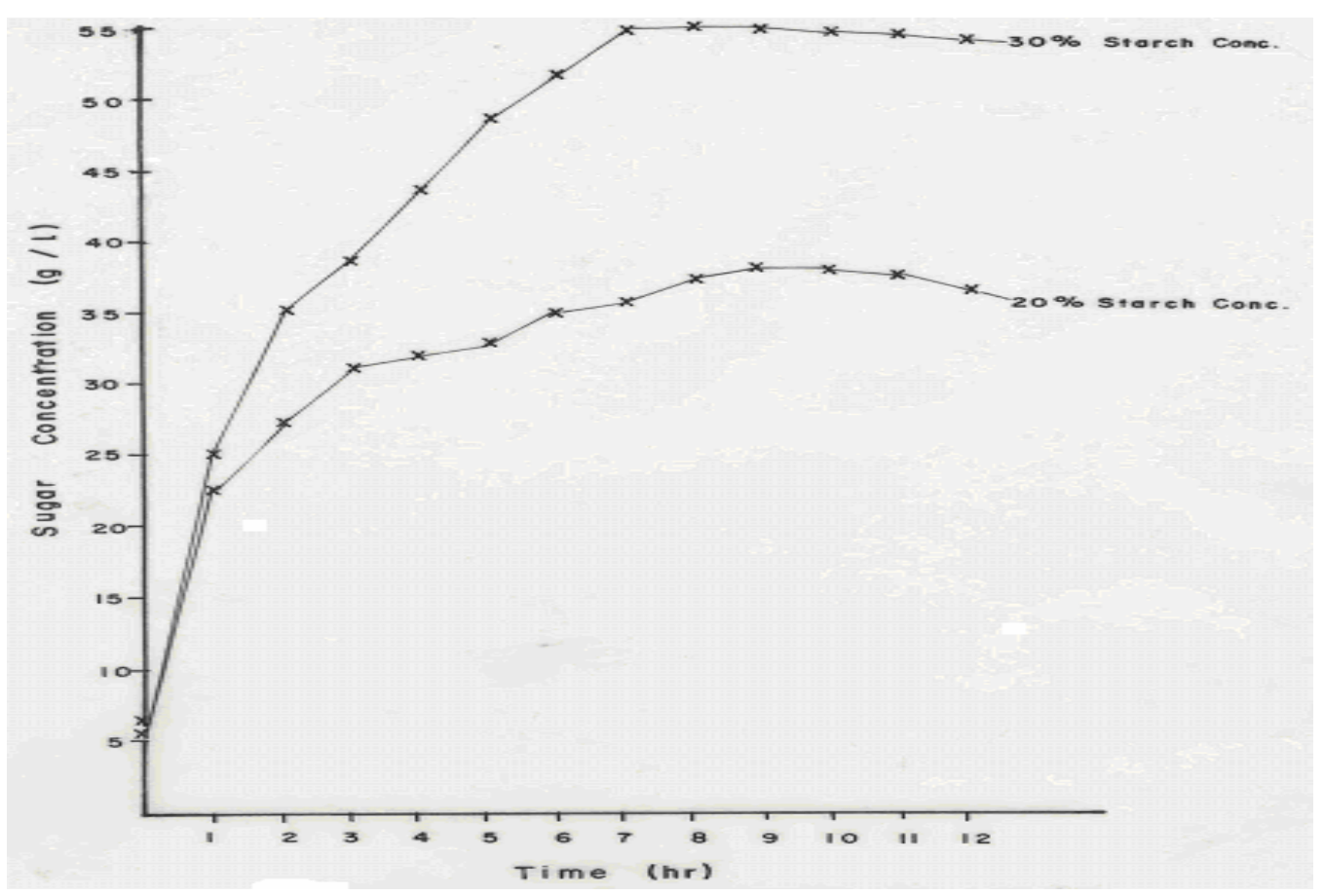

Figure 4: Effect of starch concentration on reducing sugar concentration. 


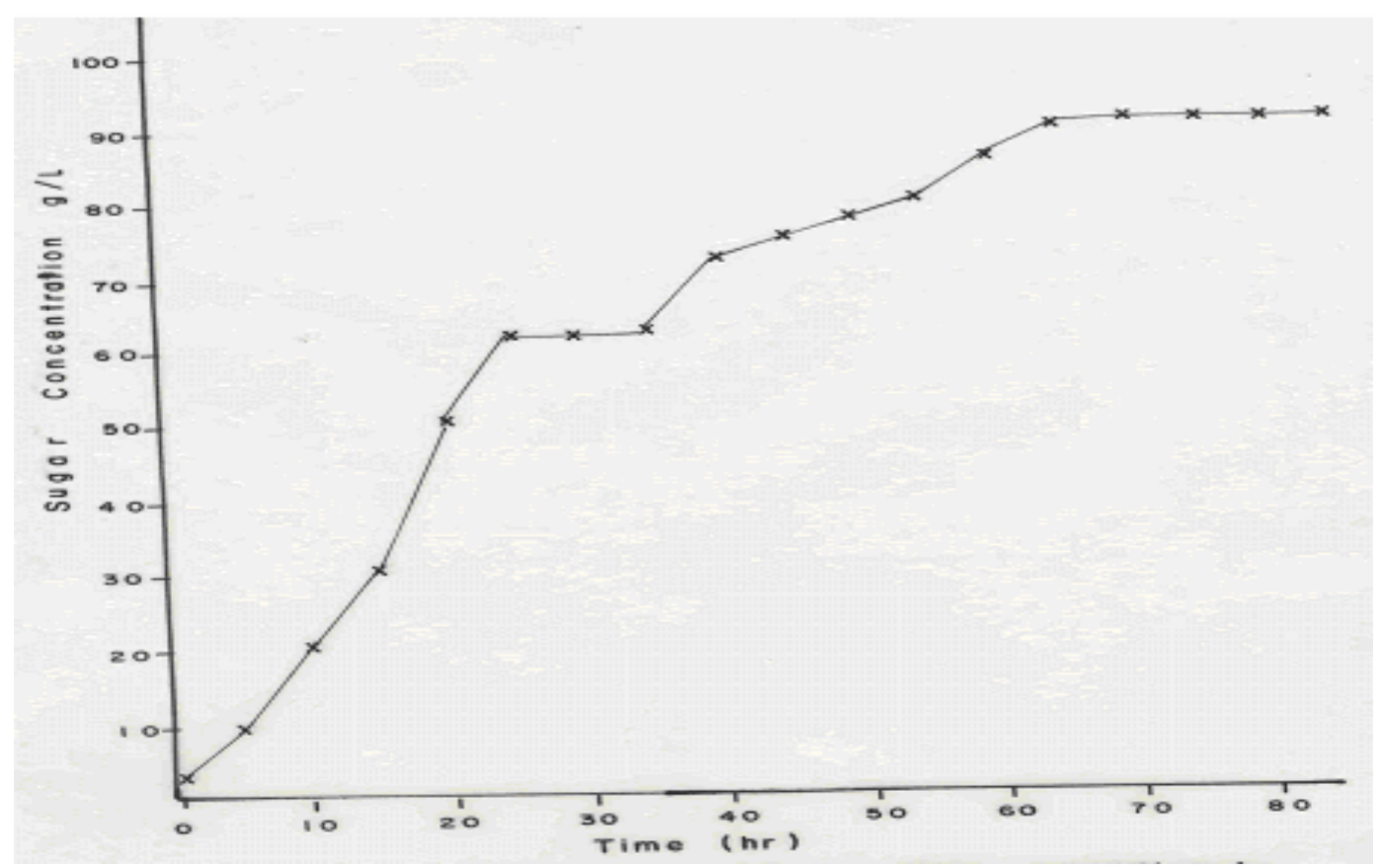

Figure 5: Variation of reducing sugar concentration (of $20 \%$ maize starch slurry) with time in $\alpha$ amylase/glucoamylase hydrolysis.

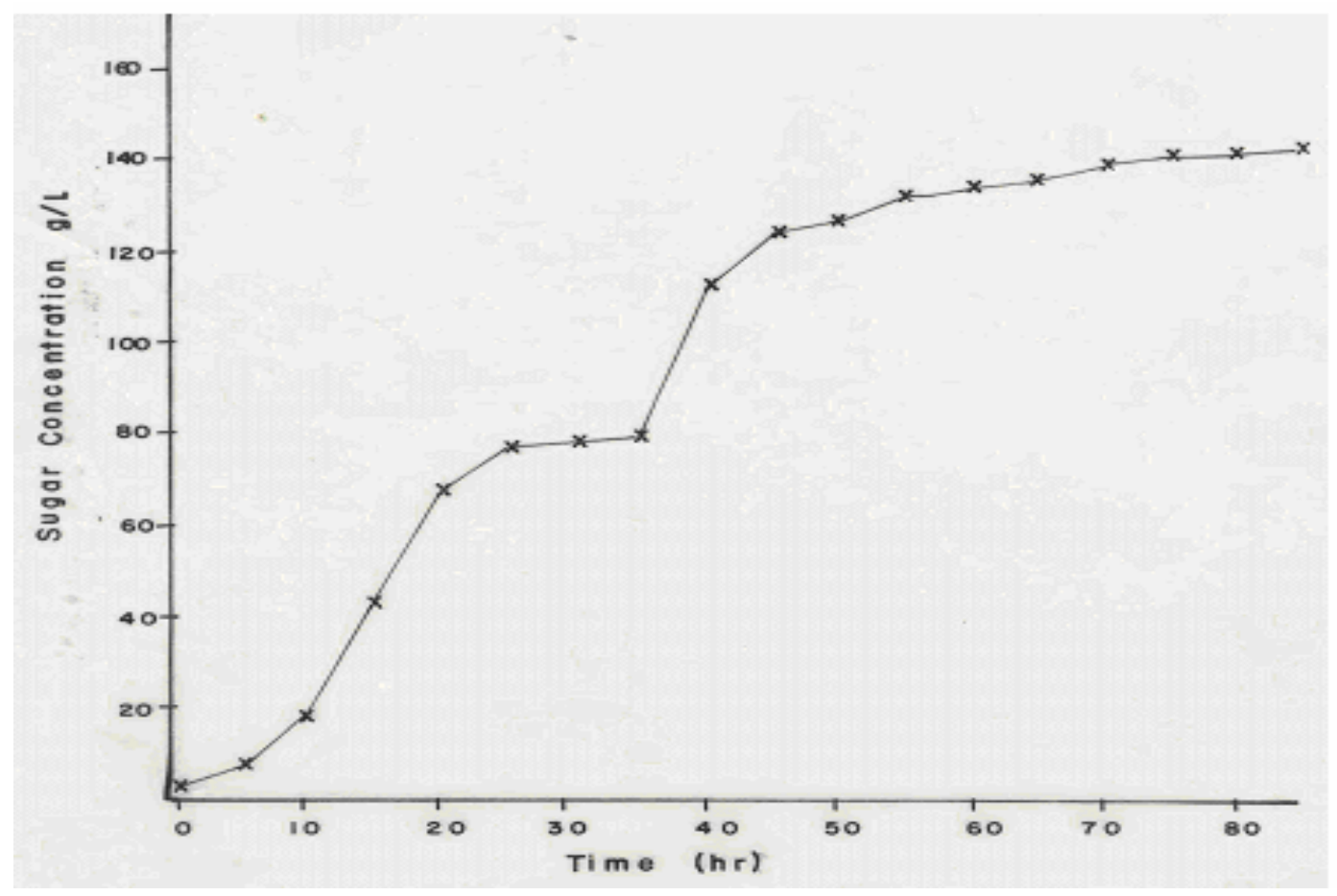

Figure 6: Variation of reducing sugar concentration (of $30 \%$ maize starch slurry) with time in $\alpha$ amylase/glucoamylase hydrolysis. 
and after $40^{\text {th }}$ hour with $85.0 \mathrm{~g} / \mathrm{L}$ sugar concentration as shown in Figure 8. After the acid hydrolysis stage in Figures 7 and 8, it was observed that the quantity of reducing sugar was lower than the quantities obtained in acid hydrolysis in Figures 1 and 2 (i.e. 38.0 $\mathrm{g} / \mathrm{L}$ and $55.2 \mathrm{~g} / \mathrm{L}$ of reducing sugar). This difference might probably be due to glucose decomposition as a result of dehydration over a long period of 20 hours (Miller and Cantor, 1952).

Over all, the DE of $34.5 \%$ and $43.0 \%$ were obtained in $20 \%$ and $30 \%$ maize starch slurry acid/enzyme hydrolysis as shown in Figures 7 and 8 compared with DE of $45.0 \%$ and $43.7 \%$ obtained in the enzyme/enzyme hydrolysis (Figures 5 and 6). Upon the fact that acid/enzyme is a three-stage hydrolysis process, yet, the DE obtained is lower than the two-stage enzyme-enzyme process. It can be reasonably suggested that side products (such as 5-hydroxymethyl furfural, furonic acid, levulinic acid, 2-hydroxyymethyl furan) probably formed during acid hydrolysis stage, inhibited the activity of $\alpha$-amylase and glucoamylase with the corresponding reduction in level of sugar produced.

The analysis of the data obtained in this study shows that malted sorghum is not only capable of developing enough amylases which can be isolated in large scale but also indicates that the activities of these amylases are also very high. In acid hydrolysis, the reducing sugar concentration produced is generally found to increase with increase in temperature. At constant acid concentration, the higher the amount of starch granules, the lower the reducing sugar produced. However, this is not so with enzyme hydrolysis. At constant temperature, the glucosidic bonds cleaved increases with increase in hydrogen ion, $\mathrm{H}^{+}$, concentration. Temperature is also found to have increasing effects on the reducing sugar produced, i.e. at constant acid concentration, the reducing sugar produced increases with temperature.

Starch hydrolyzates are very important industrial materials with highest concentration obtained from enzyme-enzyme hydrolytic procedure. The enzyme-enzyme hydrolytic

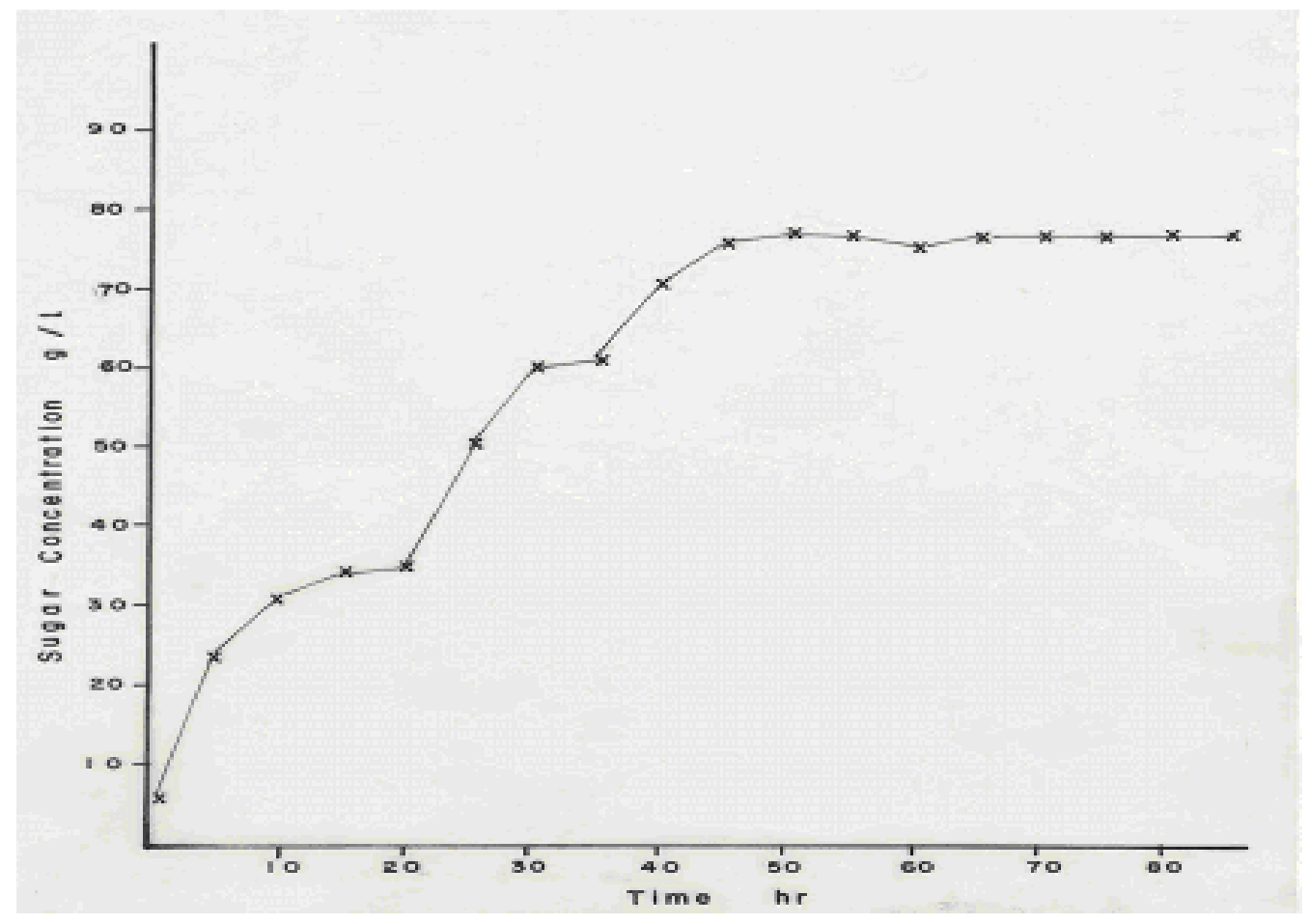

Figure 7: Variation of reducing sugar concentration (of $20 \%$ maize starch slurry) with time in $\mathrm{HCl} / \alpha$-amylase/glucoamylase hydrolysis. 


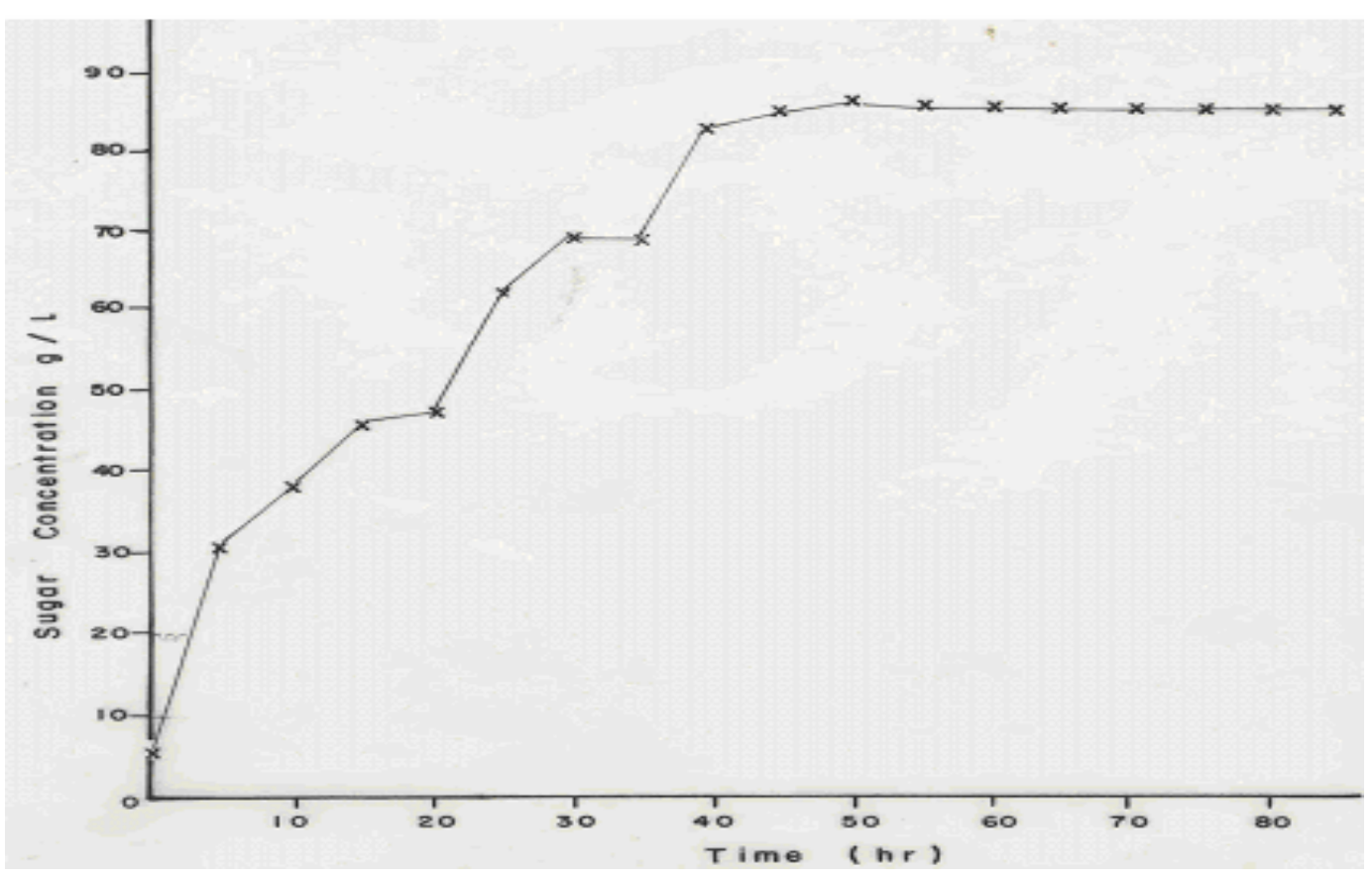

Figure 8: Variation of reducing sugar concentration (of $30 \%$ maize starch slurry) with time in $\mathrm{HCl} / \alpha$-amylase/glucoamylase hydrolysis.

procedure is preferable to acid-enzyme and acid hydrolytic procedures because it leads to higher yield and/or is easier to manipulate the conditions under which it operates. The reducing sugar obtained from the 2-step $\alpha$ amylase-glucoamylase (enzyme-enzyme) hydrolysis is higher than the 3-step $\mathrm{HCl}-\alpha$ amylase-glucoamylase (acid-enzyme) hydrolysis. Therefore, enzyme-enzyme procedure is preferable. Because the two enzymes are usually used in combination, effort has been made to fuse the genes for them and expressed it in a suitable organism (de Moraes et al., 1995, 1999).

Conventional means of producing amylases are from microbes, which are difficult to handle especially during cultivation. In addition, the cost of building a large tank for cultivation of microbes is very high, therefore producing amylases from cereals' malt would be a welcome development.

\section{REFERENCES}

Aderibigbe A. 2005. Development of hydrolytic procedure for cassava starch. MSc Thesis, Department of Chemical

\section{Engineering, Obafemi Awolowo} University, Ile-Ife, Nigeria.

Adeyemi IA. 1993. Quality considerations in the industrial utilization of maize. In Maize Improvement Production and Utilization in Nigeria. Fakorede MAB, Alofe CO, Kim SK (eds). Maize Association of Nigeria; 233-238.

Agra IB, Warnijati SO, Rijadi RS. 1969. Hydrolysis of sweet potato starch at atmospheric pressure. Journal of the Directorate General of Higher Education of Indonesia, 2(3): 34-44.

Agu RC, Palmer GH. 1997. Effect of mashing Procedures on some Sorghum varieties germinated at different temperatures. Process Biochem., 32: 147-58.

Alexander RJ. 1992. Maltodextrins production, properties and application. In Starch Hydrolysis Products. Worldwide technology, products and Applications, Schenck FW, Hebeda RE (eds). VCH Publishers: New York; 233-276.

Apar DK, Ozbek B. 2004. $\alpha$-amylase inactivation by temperature during starch hydrolysis. Process Biochem., 39: 11371144. 
Daiber KH. 1975. Enzyme inhibition by polyphenols of sorghum grains and malt. J. Food Agric., 26: 1399-1475.

Dale JK, Langlois DP. 1940. Syrup and method of making the same. United States Patent, 2: 201, 609.

De Moraes LMP, Filho SA, Ulhoa CJ. 1999. Purification and some properties of $\alpha$ amylase glucoamylase fusion protein from Saccharomyces cerevisiae. World J. Microbiol. Biotech., 15: 561-564.

De Moraes LMP, Filho SA, Olivier SO. 1990. Development of yeast strains for the efficient utilization of starch: evaluation of constructs the expressed $\alpha$-amylase and glucoamylase separately or as bifunctional fusion protein. Appl. Microbiol. Biotech., 43: 1067-1076.

Fakorede MAB. 2001. Revolutionizing Nigerian Agriculture with the Golden Seed. Inaugural Lecture Series 150. Obafemi Awolowo University, Nigeria.

Gornall AG, Bardawill CJ, David MM. 1949. Determination of serum protein by biuret reaction. J. Biol. Chem., 117: 751-766.

HRA, 1997. Starches and Hydrolyzates. A Worldwide Review of Manufactures and Production: Prairie Village, USA.

Ilori MO. 1991. The use of sorghum for beer brewing in Nigeria. Technovation, Amsterdam, 11(1): 27-37.

Job TA. 1993. Role of maize in the livestock industry. In Maize Improvement Production and Utilization in Nigeria, Fakorede MAB, Alofe CO, Kim SK (eds). Maize Association of Nigeria; 239-241.

Miller RE, Cantor SM. 1952. 2hydroxyacetyl-furan from sugar. J. Am. Chem. Soc., 74: 5236.

Muralikrishna G, Nirmala M. 2005. Cereal $\alpha$ amylases - an overview. Carbohydrate Polymers, 60: 163-173.

Nelson N. 1944. A photometric adaptation of the Somogyi method for the determination of glucose. J. Biol. Chem., 153: $375-380$.
Payen A, Persoz JF. 1835. Memoire sur la diastase, les principaux produits de ses reactions, et leurs applications aux artsindustriels. Ann. Chim (Phys)., 53: 73-92.

Peppler JH, Perlman B. 1980. Microbial technology. In Microbial Processes (Vol. 1, 2nd edn). Academic Press: New York; 30-64.

Schenck FW. 1992. Starch hydrolysis products; an introduction and history. In Starch Hydrolysis Products, Worldwide Technology, Products and Applications. Schenck FW, Hebeda RE (eds). VCH Publishers: New York; 1-22.

Solomon BO, Aderibigbe AF, Anozie AN, Betiku E. 2006. Effects of processing conditions on hydrolysis of cassava starch. Ife J. Sci., 8(2): 115-126.

Swason MA, Cori CF. 1948. Structure of polysaccharide I. Acid hydrolysis of starch-like polysaccharide. J. Biol. Chem., 172: 297-804.

Thompsons A, Ann K, Wolfrom ML, Inatome M. 1953. Acid reversion in relation to isomaltose as a starch hydrolytic product. J. Am. Chem. Soc., 76: 1309-1320.

Van Beynum GMA, Roels JA. 1985. The multidimensionality of starch conversion technology. In The Starch Conversion Technology. Van Beynum GMA, Roels JA (eds). Marcel Dekker Inc.: New York; 143-173.

Venkatasubramanian K, Keim CR. 1985. Starch and energy: technology and economics of fuels alcohol production. In The Starch Conversion Technology. Van Beynum GMA, Roels JA (eds). Marcel Dekker Inc.: New York; 143-173.

Wang YJ, Truong VD, Wang L. 2002. Structures and rheological properties of corn starch as affected by acid hydrolysis. Carbohydrate Polymers, 52: 327-333.

Whistler RL, Bemiller JN, Paschall FF. 1984. Starch Chemistry and Technology. (2nd edn). Academic Press: Orlando, USA. 